\title{
MEZŐGAZDASÁGI ÉS ÉLELMISZERIPARI HULLADÉKOK ÉS MELLÉKTERMÉKEK HASZNOSÍTÁSÁNAK LEHETŐSÉGEI
}

\author{
Lendvai Edina - Slajkó Csilla
}

\begin{abstract}
Absztrakt: Az ipari hulladékok tárolása, szállítása, megsemmisítése a logisztikai alaplépések egyik fő feladata. Munkánk során célul tüztük ki a különbözö - állati eredetü termékeket feldolgozó ágazatokban tevékenykedö élelmiszeripar vállalatok megoldásainak megismerését a fenti problémák elintézésére. Ennek érdekében interjúkat készítettünk a vállalatok képviselöivel, valamint a melléktermékeket feldolgozó ATEV Fehérjefeldolgozó Zrt-vel. A kapott információkat feldolgoztuk és kiértékeltük. Az interjúk segítségével szerettünk volna egy átfogó képet kapni a vizsgált üzemek hulladékgazdálkodási gyakorlatáról, a jövőbeni beruházások lehetőségéröl, illetve egyéb hasznosítási alternatívákról. Végül SWOT-analízis segítségével felmértük az élelmiszeripari vállalatok hulladékgazdálkodási helyzetét, és javaslatokat tettünk a felmerülö problémákra.
\end{abstract}

\begin{abstract}
We deal with agricultural and food waste and by-products, focusing on meat, poultry and dairy by-products. We have conducted interviews with the representatives of food companies working in different sectors, and with the by-product processing company, the ATEV Protein Processing Ltd. We processed and evaluated the information - had received. Our aim with the interviews was to get a comprehensive picture of the waste management practices of the analysed companies, as well as of the possibility of future investments and further ways of recycling. Lastly, we examined the situation of waste management in firms in the food industry, and I proposed solutions to the emerging problems.
\end{abstract}

Kulcsszavak: hulladék-feldolgozás, húsipar, kis- és nagyvállalat, logisztika

Keywords: waste management, meat industry, big and small companies, logistic

\section{Bevezetés}

A mezőgazdaság és az élelmiszeripar Magyarország gazdaságában mindig is meghatározó tényező volt, és feltehetőleg a jövőben is az fog maradni. Az élelmiszeripari helyzetét, illetve az élelmiszeripari vállalkozások jövedelmezőségét többek között az alapanyagok árának az utóbbi években tapasztalható növekedése, és versenytársak számának növekedése egyre inkább nehezítik.

A logisztika vállalati feladatai az alábbi föbb tevékenységek tartoznak (Bányai, 2014): Ellátás, termelés, elosztás, hulladékkezelés. Ez utóbbi esetben az újrahasznosítási logisztika feladata a termelésben elhasznált anyagok és hulladékok szakszerü, környezetbarát összegyüjtése.

Munkánk során a hazai vonatkozásban meghatározó élelmiszeripari ágazat egyes kiválasztott szereplöinek hulladékgazdálkodására vonatkozó gyakorlatát vizsgáltuk meg. Célunk a Dél-alföldi régióban müködő egyes, állati eredetü nyersanyagokat feldolgozó élelmiszeripari vállalatokat megkeresve, személyes interjúk és megbeszélések során választ keresni arra, hogy

- mennyire tartják fontosnak és meghatározónak a hulladékkezelési feladatokat az adott vállalkozás szempontjából,

- az egyes vállalatok esetében a tevékenységük során milyen típusú hulladékok és melléktermékek keletkeznek, 
- a keletkezett hulladékokat és melléktermékeket milyen formában kezelik,

- a hulladékkezelés mekkora költségekkel jár számukra,

- látják-e lehetőségét annak, hogy a saját tevékenységük során, vagy más termékpályán hasznosítsák a hulladékaikat és melléktermékeiket,

- látnak-e jelenleg lehetőséget a hulladékkezeléshez kapcsolódó és egyéb környezetvédelmi beruházásokra vonatkozóan.

A magyarországi hulladékgazdálkodásra vonatkozó rendelkezések szoros összhangban állnak az Európai Unió környezetvédelmi politikájával. A hulladékról szóló 2012. évi CLXXXV. törvény az Európai Közösség jogi normáival összeegyeztetett szabályozást tartalmaz, így Magyarországon is az Európai Unió irányelvei a mértékadók. Hosszú távon mind az Európai Uniónak, mind Magyarországnak célja a fenntartható fejlődés biztosítása a természeti eröforrásokkal való takarékos bánásmód által (Szlávik, 2005). Ennek értelmében mérsékelni kell a nem megújuló erőforrások kitermelését, valamint politikai és gazdasági eszközökkel is ösztönözni kell a hatékony és takarékos anyag-, illetve energiafelhasználást a környezet lehető legkisebb mértékü terhelése érdekében (Klessmann et al., 2011). A magyar környezetvédelmi politika a „Környezet védelmének általános szabályairól" szóló 1995. évi LIII. Törvényben rögzítette alapvető elveit és céljait (Bándi, 2002). A környezetvédelmi tevékenységeken belül a hulladékgazdálkodás elveit és alapvető szabályait az idén életbelépő - a hulladékgazdálkodásról szóló 2000. évi XLIII. törvényt felváltó - a hulladékról szóló 2012. évi CLXXXV. törvény határozza meg. Az új hulladékgazdálkodási törvény a hulladékgazdálkodásról szóló 2000 . évi XLIII. törvényen alapszik, amely lefekteti a hulladékgazdálkodás alapelveit, megalapozza a hulladékgazdálkodás szervezését, meghatározza a gyártó, forgalmazó és a fogyasztó kötelezettségeit, a hulladékhasznosítás és -kezelés módszereit, valamint rendelkezik a veszélyes hulladékokkal kapcsolatos intézkedésekröl. (Hegóczki et al., 2009). A jelenleg hatályos, Országos Hulladékgazdálkodási Terv 2017, dokumentum megfelel a kormányzati stratégiai irányításról szóló 38/2012. (III. 12.) Kormányrendelet elöírásainak, úgynevezett. cselekvési terv. Az OHKT bemutatja és tartalmazza a 2016. április 1. és 2016. október 31. közötti időszak hazai közszolgáltatást érintő hulladékgazdálkodási eredményeit, helyzetértékelést ad az eltelt időszakra vonatkozóan, és magában foglalja a 2017-es évre vonatkozó közszolgáltatási szakmapolitikai célkitüzéseket, a szakterületi célok eléréséhez szükséges intézkedéseket. Emellett figyelembe veszi az OHT 2014-2020 közötti előrejelzéseit is (Országos Hulladékgazdálkodási Közszolgáltatási Terv, 2017)

A 2012. évi CLXXXV. törvény szerint a hulladékgazdálkodás a következö tevékenységekre terjed ki:

- a hulladék gyüjtése és szállítása,

- a hulladék kezelése,

- ezen tevékenységek felügyelete,

- a kereskedőként vagy közvetítőként végzett tevékenység,

- a hulladékgazdálkodási létesítmények és berendezések üzemeltetése,

- a hulladékkezelő létesítmények utógondozása. 
A hulladékról szóló törvény a következő feltételeket szabja ki a hulladékgazdálkodási tevékenységekre:

- a tevékenységet az emberi egészség, és a környezet veszélyeztetése nélkül kell végezni

- a tevékenység ne jelentsen kockázatot a környezeti elemekre,

- ne okozzon lakosságot zavaró zajt vagy büzt,

- ne befolyásolja hátrányosan a tájat, a védett természeti és kulturális értékeket.

A hulladék fogalmát a legegyszerübben úgy lehet megfogalmazni, hogy mindaz, ami nem kell, ami felesleges, amit a szemétbe szánunk.

Vannak olyan anyagok, termékek, amelyek számunkra értéktelenek azonban máshol mások számára ezek az anyagok hasznos nyersanyagként jelennek meg.

Ezek miatt a következő általános definíció érvényes a hulladék fogalomra: „Hulladék a termelö, szolgáltató vagy fogyasztói tevékenység során, vagy ezek következtében keletkező - tulajdonosa által rendeltetése szerint fel nem használt, illetve a keletkezés folyamatába vissza nem vezetett, vagy arra alkalmatlan maradékanyag, elhasználódott, illetve selejtté vált termék." (Vermes, 2005)

A legújabb megfogalmazásban a hulladékokról szóló 2012. évi CLXXXV. törvény szerint hulladéknak minősül „,bármely anyag vagy tárgy, amelytől birtokosa megválik, megválni szándékozik vagy megválni köteles."

A hulladékok többféle szempontrendszer alapján csoportosíthatóak. Leggyakrabban az eredet szerinti csoportosítást alkalmazzák, mely szerint a következő hulladékokat különböztetjük meg (Thyll, 2004):

- termelési (ipari, mezőgazdasági, szolgáltatási)

- települési (kommunális)

Halmazállapotuk szerint négy csoportba lehet sorolni a hulladékokat:

- szilárd

- folyékony

- iszapszerü

- gáznemü hulladék

Az utóbbi csoportosítás nem túl pontos, hiszen a különböző csoportokon belül beltartalom szerint igencsak heterogén hulladékcsoportok szerepelhetnek. Emiatt, illetve a hatályos jogi szabályozás miatt például a radioaktív hulladékok a kezelés szempontjából külön csoportot képeznek, illetve a kibocsátás és a szennyezettség szempontjából a légszennyező anyagokra esetében is speciális szabályozás érvényes (Bándi, 2002).

Minden termelési folyamat következtében keletkeznek számunkra fontos melléktermékek. A melléktermékek a főtermékek mellett felesleges anyagokká válnak, azonban egy másik termelési folyamat kiindulási anyagaként teljes értékü nyersanyagként szolgálnak. (Vermes, 2005)

Magyarországon évente közel 114 millió tonna hulladék keletkezik, ebböl körülbelül 90 millió tonna lév az ipari, mezőgazdasági vagy más gazdasági tevékenységböl származó termelési hulladék. A termelési hulladékokon belül 
megközelítőleg 3,5 millió tonna az évenként keletkező veszélyes hulladék mennyisége (1. ábra).

\section{1. ábra: Magyarországon keletkezett hulladékok és fajtáik}

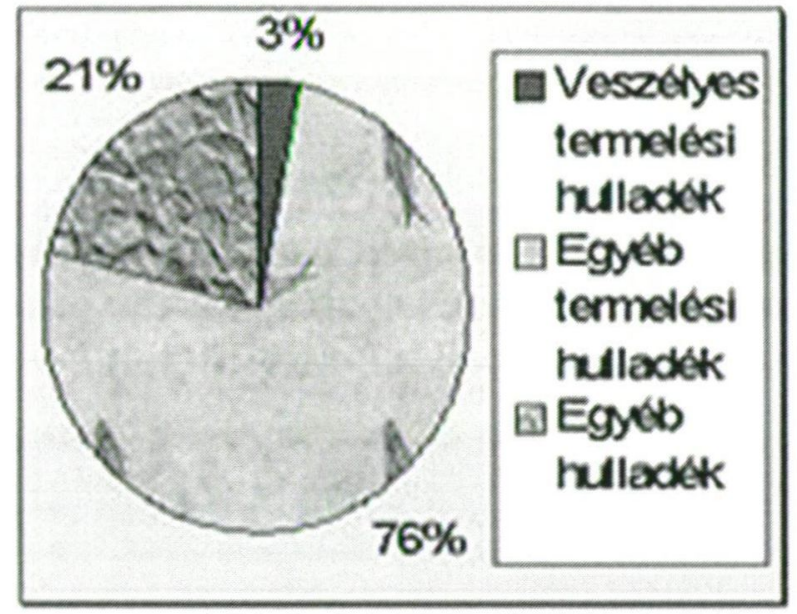

Forrás: www.foek.hu

A 2012. évi CLXXXV. törvény a hulladékokról a következőképpen fogalmazta meg a melléktermék definícióját. „Valamely anyagot vagy tárgyat, amely olyan előállítási folyamat során képződik, amelynek elsődleges célja nem az ilyen anyag vagy tárgy elöállítása, a következő feltételek együttes teljesülése esetén nem hulladéknak, hanem mellékterméknek tekinthető és kezelhető:

a) további felhasználása biztosított,

b) előállítását követően - a szokásos ipari gyakorlattól eltérő feldolgozás nélkül - közvetlenül felhasználható,

c) az előállítási folyamat szerves részeként állítják elö,

d) a környezetet és az emberi egészséget hátrányosan nem érinti, és

e) további használata jogszerü, azaz meghatározott módon történő felhasználása tekintetében az anyag vagy tárgy megfelel a termékre, a környezet- és egészségvédelemre vonatkozó összes jogszabályi elöírásnak."

\section{Anyag és módszer}

Kutatásunk során három élelmiszeripari ágazatban (hús-, baromfi-, illetve tejipar) egy nagy, és egy kis/közepes üzemméretủ vállalattal készítettünk interjút az összehasonlíthatóság érdekében. A részt vevő vállalkozások a következők:

Húsiparon belül:

- $\quad$ Pick Szeged Zrt. (Szeged)

- Beck Hús Kft (Csávoly)

Baromfiiparon belül:

- Gallicoop Zrt. (Szarvas)

Tejipar: 
- Mizo Zrt. (Bácsbokod)

- Boppe Kft. (Hódmezővásárhely)

A cikkben a húsipari vállalatok vezetőivel késztett interjúk eredményeit ismertetjük.

\section{Eredmények és értékelésiik}

A továbbiakban néhány fontosabb kérdésre kapott válaszokat mutatjuk be röviden. Elsőként az egyes vállalatoknál keletkezett hulladékok mennyiségeit ismertetjuik- a kapott adatok alapján.

$\mathrm{Az}$ 1. táblázat adatainak vizsgálatával belátható, hogy a vállalat termelési volumenével egyenes arányosságban nő a keletkezett melléktermékek mennyisége, valamint az is megállapítható a Pick Szeged Zrt. esetében, hogy a nagyobb foglalkoztatottsági létszám mellett és a termékek csomagolása során a keletkezett kommunális hulladékok mennyisége is jelentős mértékben több, mint a Beck Hús Kft-nél.

1. táblázat: Keletkezett hulladékok és melléktermékek típusa és mennyisége

\begin{tabular}{|c|c|c|c|c|}
\hline & Pick Szeged Zrt. & Beck Hús Kft. \\
\hline \multirow{6}{*}{\multicolumn{2}{|c|}{ 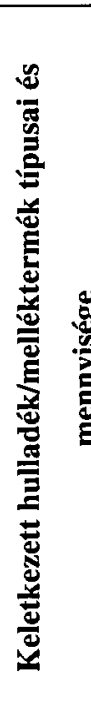 }} & Kommunális & $753455 \mathrm{~kg} / \mathrm{e} v$ & $1500 \mathrm{~kg} / \mathrm{év}$ \\
\hline & & Szennyviz & $595842 \mathrm{~m} 3 /$ év & $400 \mathrm{~m}^{3} / e^{2} v$ \\
\hline & & Szennyviziszap & $1965841 \mathrm{~kg} / \mathrm{év}$ & n.a. \\
\hline & & $\begin{array}{c}\text { Bél és } \\
\text { béltartalom }\end{array}$ & $\begin{array}{r}\text { Központi telep: } 121877 \mathrm{~kg} / \mathrm{v} v \\
\text { A Maros utcai Gyáregységben nincs } \\
\text { állatvágás. }\end{array}$ & $\begin{array}{r}(2,5-3 \mathrm{~kg} / \text { garnitúra } \cdot 10000 \\
\mathrm{db} \text { sertés/év) } \\
27500 \mathrm{~kg} / \mathrm{év}\end{array}$ \\
\hline & & $\begin{array}{c}\text { Kobzás/állati } \\
\text { hulla }\end{array}$ & Központi telep: $216192 \mathrm{~kg} / \mathrm{e} v$ & $29200 \mathrm{~kg} / \mathrm{év}$ \\
\hline & 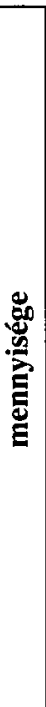 & Vér & Központi telep: 2309040 kg/év & $\begin{array}{r}(2,5-3 \text { liter/sertés } \cdot 10000 \\
\text { db sertés/év }) \\
27500 \text { liter/év }\end{array}$ \\
\hline
\end{tabular}

Forrás: Saját kutatás

A Pick Szeged Zrt. telephelyén saját szennyvíz előkezelés történik, fizikai és kémiai szennyvíztisztítást alkalmazva, majd egyesített formában a szociális szennyvízzel, az ipari tisztított szennyvízzel és a csapadékvízzel egyuitt a városi közcsatornába bocsátják. A közmüves szennyvíztisztítás költsége a Pick Szeged Zrt. esetében a Szegedi Vízmű Zrt. által megállapított csatorna használati díj, amelyet a kibocsátott víz után kell fizetni. A Beck Hús Kft-nél csak előzetes mechanikai szennyvíztisztítás történik. Elökezelést követően a leszürt szennyvizet konténerekbe 
gyüjtik, amit a városi szennyvíztisztítóba szolgáltatnak be, ahol a szennyvíz további tisztítását végzik. Ennek költsége, a Beck Hús Kft. esetében meghaladja a havi 200000 forintot. Megkérdezésünkre mindkét társaság azt válaszolt, hogy nem tervez saját szennyvíztisztító létesítését mivel az általuk alkalmazott technológia kiszolgálja rendszerüket, valamint gazdasági megfontolásból nem lenne megtérülő. Bevallásuk szerint túl kicsik egy ilyen technológia kiépítéséhez, ezért nem tudják kikerülni a szennyvíz járó magas költségeket.

$\mathrm{Az}$ állati eredetü hulladékok sorsával kapcsolatos kérdésünkre interjúalanyaink egyöntetüen az ATEV Fehérjefeldolgozó Zrt-t említették meg, mint teljeskörü és kizárólagos lehetőség a melléktermékek további hasznosítására, illetve ártalmatlanítására. A melléktermékek további kezelésével járó költségek hatalmasak, mind a nagy vállalatok, mind a kis üzemek részére A PICK esetében 100 millió, a BECK HÚSnál kb. 3 millió Ft évente.

Annak érdekében, hogy a két vállalat összehasonlítható legyen egy fajlagos mutatót dolgoztunk ki. Ezzel a két vállalat 1 kilogrammra jutó hulladékkezelési költségét tudjuk összevetni. A számítás során a következő képletet használtuk:

$$
\mathrm{R} \frac{\sum \text { évi hulladékkezelési költség }}{\sum \text { évi termelési volumen }}
$$

Ez az érték a Pick Zrt. esetében a következőképpen alakult:

$(100000000 \mathrm{Ft} / e ́ v) /(200000 \mathrm{~kg} / \mathrm{nap} 250$ munkanap $)=2 \mathrm{Ft} / \mathrm{kg}$

Ugyanez a számítás a Beck Hús Kft. vonatkozásában:

$(2980000 \mathrm{Ft} / e ́ v) /(4400 \mathrm{~kg} / \mathrm{nap} \cdot 250$ munkanap $)=\underline{2,709 \mathrm{Ft} / \mathrm{kg}}$

A kapott értékek csak hozzávetőleges adatok, viszont segítenek a vállalatok hatékonyságának összehasonlításában, amelynek következtében a következö állítások vonhatók le. A termelési volumen és a teljes éves hulladékkezelési költség figyelembevételével számított fajlagosa mutató alapján megállapítható, hogy a Pick Szeged Zrt. esetében, elsősorban a nagyobb kapacitás, és a rendelkezésre álló magasabb színvonalú szennyvíz előkezelési és hulladékkezelési technológia miatt a fajlagos hulladékkezelési költségek már jelenleg is alacsonyabbak. Mindezek alapján szintén belátható, hogy a sertésfeldolgozásban érdekelt hazai kis- és közepes méretü élelmiszeripari vállalatok számára a hulladékkezelési költségek összességében alacsonyabbnak hatnak, azonban fajlagosan magasabbak, ami a jövedelmezőségi mutatóikat rontják.

A keletkezett hulladékok tárolásával kapcsolatosan az alábbi információkhoz jutottunk. A Pick Zrt-től részletes információkat kaptunk a különböző hulladékok és melléktermékek tárolására vonatkozóan. Üzemi szinten speciális, rozsdamentes forgófedeles edényekbe külön gyüjtik a sertésvágó és a szalámi üzemben keletkező csontokat, valamint ide kerülnek a vegyes kobzásnak nevezett, hulladékká vált állati szövetek (pl. csontozás során leváló húsdarabok). A szőr a szörtelenítés után csővezetéken keresztül átfúvatva a hulladékudvarba kerül, valamint levágás során keletkezett nagy mennyiségü vért is csővezetékeken keresztül tartályokba gyüjtik. A 
Beck Hús Kft-nél a keletkezett mellékterméket nagy hütőtárolókba gyüjtik, és azokban tárolják öket elszállításukig. Arra a kérdésemre, miszerint az Európai Unió elött, hogy oldották meg ezen anyagok tárolását, mindketten azt válaszolták, hogy ugyanígy oldották meg, mint jelenleg.

A hulladékok hasznosítására vonatkozó kérdések alapján kiderült, a vállalatok által termelt melléktermékek saját maguk által történő hulladékhasznosítása különböző felmerülő problémák miatt nem igen elterjedt Magyarországon. Ez a lehetőség elsősorban az üzem termelési volumenétől függ, kis üzem esetében egyáltalán nem jelenik meg, illetve függ a telephelyi adottságoktól, pályázati forrásoktól. A Pick Szeged Zrt. esetében azért nem végeznek közvetlen hulladékhasznosítást, mert nem keletkezik olyan melléktermék, amit helyben lehetne hasznosítani, emellett a telephelyi adottságok sem teszik lehetővé ezt a fajta tevékenységet. A Beck Hús Kft. munkatársa pedig azt nyilatkozta, hogy ez a fajta hasznosítás nem jellemzö a húsiparon belül.

A képződő melléktermékek aránya a felhasznált nyersanyaghoz képest - az interjúalanyunk az alábbiakat osztotta meg velünk: a melléktermékek aránya a Pick Szeged Zrt. esetében a következő képlettel határozható meg.

$$
\text { Bruttó melléktermék }=\frac{\sum \text { állati melléktermék kg/év }}{\sum \text { levágott sertés db/év }}
$$

E képlet alapján, az így kiszámolt érték korábban $41,26 \mathrm{~kg} / \mathrm{db}$ bruttó melléktermék arány volt, ami azt jelenti, hogy az átlagos súlyú levágott sertés darabonként fennmaradó bruttó mellékterméke átlagosan $40 \mathrm{~kg}$ körüli. Ez az érték idén januártól áprilisig valamivel kevesebb, $37,44 \mathrm{~kg} / \mathrm{db}$.

A Beck Hús Kft-nél a veszélyes hulladékok aránya a levágott élősúlyhoz képest körülbelül $10 \%$, ez egy átlagos $100-110 \mathrm{~kg}$-os sertésnél 10-11 kg-ot jelent. Ez az arány azért kevesebb, mivel a Beck Hús $\mathrm{Kft}$. csávolyi telephelyén csak vágás történik, nem végeznek csontozást, illetve darabolást. Ennek következtében a melléktermékek aránya értelemszerüen nem nő. Melléktermékként ebben az estben csak a szemet, a fülgombát, a gyomrot, illetve a vért lehet tekinteni. Továbbá, a vezető elmondása szerint a Beck Hús Kft-nek más a termékszerkezete, valamint csontozási metodikát alkalmaznak, mint a Pick Szeged Zrt-nél.

Jelentési kötelezettségek az állati eredetü hulladékokról- ezzel kapcsolatosan mindkét interjúalany elmondta, hogy jelenleg az új típusú adatszolgáltatás a vidékfejlesztési miniszter a nem emberi fogyasztásra szánt állati eredetü melléktermékekre vonatkozó állategészségügyi szabályok megállapításáról szóló 45/2012. (V. 8.) VM rendelete alapján történik, amely szerint a vállalatoknak az Állategészségügyi és Élelmiszerlánc Ellenőrző Hivatal felé van jelentési kötelezettségük, felváltva a korábbi területileg illetékes környezet védelmi hivatal felé tett jelentésüket. A rendelet emellett kötelezővé teszi az állati eredetü melléktermékek mennyiségének az egyes hulladékkategóriák szerinti feltüntetését. 
Az esetleges hulladékcsökkentő technológiák alkalmazásával kapcsolatosan a két szakember egybehangzóan azt válaszolta, hogy a sertéságazatban egyértelmüen kijelenthető, miszerint nincs lehetőség a hulladékcsökkentő feldolgozó technológiák alkalmazására az állati eredetü melléktermékek csökkentése érdekében. Hulladékcsökkentési alternatívákat egyedül a szennyvízkezelés során, illetve a kommunális hulladékokra vonatkozásában tudnak alkalmazni.

A hulladékkezeléshez kapcsolódó pályázati forrásokról, ár az EUban igen jelentős lehetőségek vannak. A vizsgált vállalkozásoknál azonban elég alacsony szinten mérhető a beruházási kedv, ez valószínüleg a magas önrész arány, valamint a különböző pályázati feltételeknek való megfelelés miatt realizálható. A Beck Hús Kft. jelenleg nem pályázik ilyen jellegü beruházásokra. A Pick Szeged Zrt-nél azonban nemrég kezdődött el egy $\mathrm{K}+\mathrm{F}$ pályázat, Ennek sikeressége - az interjú időpontjában - azonban még bizonytalan volt.

\section{Következtetések, javaslattétel}

Kutatásunk végén az elhangzott interjúk alapján egy SWOT analízist végeztünk, melynek eredményeit mutatja be a 2. táblázat. Szeretnénk kiemelni, hogy bár jelent tanulmányban csak a húsipari cégek vezetőivel készített interjút elemeztük, a SWOT a másik két ágazat interjúinak eredményeit is tartalmazza.

Kutatásunkban a kiértékelt interjúk alapján kiderült, hogy igen fontosak a hulladékkezelési feladatok az egyes élelmiszeripari vállatok vonatkozásában. Megvilágításra került az állati eredetủ melléktermékek sorsa, hogy egészen keletkezésüktől az újrafeldolgozásukig milyen folyamatokon kell átesniük. Emellett a hulladékkezelési költségekre vonatkozó vizsgálatokból megállapítható, hogy mind az állati eredetü anyagok, mind a szennyvíziszap kezelési költsége igen magas, amely nagymértékben növeli a vállalatok kiadásait, hiszen az anyagok újrafeldolgozása által létrejött jól értékesíthető termékek utáni bevételek nem az üzemeknél, hanem a fehérjefeldolgozó társaságoknál realizálódik. Az Európai Uniós források esetében nagymértékü támogatásokra, ágazati integrációkra lenne szükség egy hatékonyabb, jobban a hulladékhasznosításra támaszkodó hulladékfeldolgozási eljárás kiépítéséhez. Jelenleg a hulladékkezeléshez kapcsolódó és egyéb környezetvédelmi beruházások nem megfelelően ösztönzöttek, illetve a vállalatok nem rendelkeznek megfelelő kapacitással e tevékenységek folytatására. 
2. táblázat: A kutatás alapján elvégzett SWOT analízis összefoglaló táblázata

\begin{tabular}{|c|c|c|}
\hline \multirow{7}{*}{ 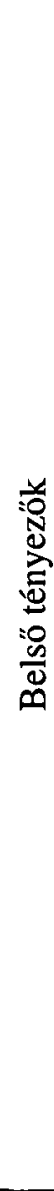 } & Erősségek & Gyengeségek \\
\hline & $\begin{array}{c}\text { Az eddig jól szabályozott és kevés } \\
\text { szereplős hulladékártalmatlanítással } \\
\text { és hasznosítással foglalkozó } \\
\text { vállalkozások jól szervezett gyüjtő és } \\
\text { hatékony feldolgozási } \\
\text { technológiákkal rendelkeznek }\end{array}$ & $\begin{array}{l}\text { A szolgáltatókkal való, elsősorban } \\
\text { hasznosítást lehetővé tevő } \\
\text { együttmüködés gyengeségei }\end{array}$ \\
\hline & $\begin{array}{c}\text { Az ártalmatlanító létesítmények } \\
\text { megfelelnek a jelenlegi } \\
\text { környezetvédelmi követelményeknek }\end{array}$ & $\begin{array}{l}\text { Az élelmiszeripari üzemekben is } \\
\text { alkalmazható korszerü } \\
\text { hulladékkezelési és hasznosítási } \\
\text { technológia magas beruházási } \\
\text { költségei }\end{array}$ \\
\hline & $\begin{array}{c}\text { A fehérjefeldolgozók } \\
\text { kapacitásnövelésére nincs szükség }\end{array}$ & $\begin{array}{c}\text { Magas hulladékkezelési, - } \\
\text { hasznosítási és ártalmatlanítási díjak }\end{array}$ \\
\hline & $\begin{array}{l}\text { A szigorú hazai állategészségügyi } \\
\text { szabályozás miatt az állati } \\
\text { hulladékok hasznosítása esetében } \\
\text { nem adódott fertőzés- és } \\
\text { járványveszély } \\
\end{array}$ & $\begin{array}{l}\text { Az energetikai hasznosítás esetén } \\
\text { egyes esetekben az ,,alapanyagokat” } \\
\text { adó élelmiszeripari vállalkozások } \\
\text { nem részesülnek a profitból }\end{array}$ \\
\hline & $\begin{array}{l}\text { A nagy kapacitással rendelkező } \\
\text { feldolgozóüzemek esetében az } \\
\text { előírásoknak megfelelő hatékony } \\
\text { hulladéktárolási technológia }\end{array}$ & Szúkös a komposztfelvevök piaca \\
\hline & $\begin{array}{c}\text { A nagyobb méretü vállalatoknál } \\
\text { jelenleg is rendelkezésre állnak a } \\
\text { megfelelően képzett } \\
\text { környezetvédelmi szakemberek }\end{array}$ & $\begin{array}{c}\text { Egyes élelmiszeripari vállaltoknál a } \\
\text { hulladékot kezelő vállalkozások } \\
\text { földrajzilag nagy távolságban } \\
\text { vannak }\end{array}$ \\
\hline \multirow{5}{*}{ 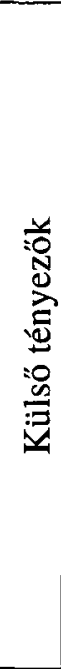 } & Lehetöségek & Veszélyek \\
\hline & $\begin{array}{c}\text { Az EU új költségvetésében szereplö } \\
\text { esetleges magasabb } \\
\text { környezetvédelmi beruházási } \\
\text { források }\end{array}$ & Jogi szabályozások szigorodása \\
\hline & $\begin{array}{l}\text { A feldolgozó üzemek közötti ágazati } \\
\text { integráció erösítése }\end{array}$ & $\begin{array}{c}\text { Esetleges újabb állati } \\
\text { megbetegedések, fertőzések } \\
\text { megjelenése, amely a hasznosítási } \\
\text { eljárások elterjedését tovạ́bb } \\
\text { nehezítheti }\end{array}$ \\
\hline & Energetikai hasznosítás bővítése & \multirow[b]{2}{*}{$\begin{array}{l}\text { Az új hulladékgazdálkodási törvény } \\
\text { értelmében a gyüjtést és hasznosítás } \\
\text { végző új szereplőkkel való jövőbeli } \\
\text { együttmüködési lehetőségek } \\
\text { egyelöre nem kellően tisztázottak }\end{array}$} \\
\hline & $\begin{array}{c}\text { Komposztok, szennyvíziszapok } \\
\text { mezögazdasági felhasználásának } \\
\text { növelése az élelmiszeripari üzemek } \\
\text { integrációs partnereinél }\end{array}$ & \\
\hline
\end{tabular}




\section{Irodalomjegyzék}

2012. évi CLXXXV. törvény a hulladékról.

Bándi Gy. (2002): Hulladékgazdálkodási Kézikönyv I. Complex Kiadó, Budapest.

Bányai Tamás (2014): A logisztika alapjai. Budapesti Gazdasági Föiskola, Budapest.

Grafikonok a magyarországi hulladékgazdálkodás állapotáról <http://www.foek.hu/korkep/hulladek/4-1-2-d-.html> (2017.10.10.)

(2004).

Hegóczki J., Pándi F., Vereczkey G. (2009): Élelmiszer-ipari hulladékok statisztikája. Statisztikai Szemle, 87 (3): 288-301.

Klessmann, C., Held, A., Rathmann, M., Ragwitz, M. (2011): Status and perspectives of renewable energy policy and deployment in the European Union - What is needed to reach the 2020 targets? Energy Policy, 39 (12): 7637-7657.

Országos Hulladékgazdálkodási Közszolgáltatási Terv (2017) https://nhkv.hu/wpcontent/uploads/2013/12/OHKT_felulvizsgalat_2017_NHKV.pdf?dl=1 (2017.10.10.)

Szlávik János (2005): Fenntartható környezet- és erôforrás gazdálkodás. Complex Kiadó, Budapest. Thyll Szilárd (2004): Környezetgazdálkodás a mezőgazdaságban. Mezőgazda Kiadó, Budapest.

Vermes László (2005): Hulladékgazdálkodás, hulladékhasznosítás. Mezőgazda Kiadó, Budapest. 